\title{
PERAN GENDER PADA ENTREPRENEURIAL MINDSET DAN ENTREPRENEURIAL MARKETING: STUDI PADA MAHASISWA FAKULTAS EKONOMI UNIVERSITAS SEMARANG
}

\author{
Gender Roles in the Entrepreneurial Mindset Marketing and Entrepreneurial Studies On \\ Students of the Faculty of Economics, University of Semarang \\ Nuria Universari, Yuli Budiati \\ Fakultas Ekonomi Universitas Semarang
}

\begin{abstract}
ABSTRAK
Tujuan penelitian ini adalah untuk menganalisis entrepreneurial mindset dan entrepreneurial marketing mahasiswa. Mahasiswa yang digunakan sebagai sampel adalah mahasiswa jurusan manajemen Universitas Semarang yang sedang mengambil mata kuliah seminar manajemen pemasaran, untuk membedakan entrepreneurial mindset dan entrepreneurial marketing antara mahasiswa pria dan wanita.

Data diperoleh melalui survey dengan instrument penelitian berupa kuesioner. Kuesioner yang didistribusikan kepada responden berjumlah 85 tetapi yang kembali dan digunakan untuk analisis hanya 72 .

Hasil penelitian menunjukkan bahwa tidak ada perbedaan antara entrepreneurial mindset dan entrepreneurial marketing mahasiswa pria dan mahasiswa wanita. Akses pendidikan yang sama antara mahasiswa pria dan wanita membuat tidak ada perbedaan antara entrepreneurial mindset mahasiswa pria dan wanita. Universitas tidak membedakan perlakuan antara mahasiswa pria dan mahasiswa wanita dalam penerimaan program pendidikan kewirausahaan serta program-program kewirausahaan lainnya sehingga membawa dampak pada tidak adanya perbedaan dalam penilaian kepentingan dimensi entrepreneurial marketing antara mahasiswa pria dan wanita.
\end{abstract}

Kata kunci: entrepreneurship mindset, entrepreneurship marketing, entrepreneurship education, teori feminisme sosial, gender

\begin{abstract}
The objective of this research is to analize entrepreneural mindset and entrepreneurial marketing of the student. This study used a sample of student that have management major and attending marketing management seminars in Semarang University to distinguish entrepreneurial mindset and entrepreneurial marketing between male students and female student.

Data were derived from the survey, where the research instrument used was questioners. These were distributed to 85 respondents, however only 72 that were returned and analyzed.

The finding show that there is no difference between entrepreneurial mindset and entrepreneurial marketing among male students and female student. It can be concluded that the same access to education between male and female students make no distinction between the entrepreneurial mindset of male and female students. University do not differentiate treatment between male students and female students in receipt of entrepreneurship education programs and other entrepreneurship programs. So there is no differences between the entrepreneurial marketing of male and female students..
\end{abstract}

Keywords: entrepreneurship mindset, entrepreneurship marketing, entrepreneurship education, socialist feminism theory, gender

\section{PENDAHULUAN}

\section{Latar Belakang Masalah}

Pendidikan kewirausahaan merupakan salah satu faktor yang penting bagi pertumbuhan ekonomi baik di negara maju maupun di negara berkembang (Millman \& Matlay, 2008; Matlay, 2009 dalam Peltier \& Scovotti, 2010). Menurut
Kuratko (2004) pendidikan kewirausahaan adalah sebuah proses dinamis dan sosial dari seseorang baik secara individu maupun kolaborasi kelompok, mengidentifikasi peluang untuk inovasi dan tindakan dengan mentransformasikan ide ke dalam praktik dan aktivitas yang telah ditargetkan baik dalam konteks sosial, kebudayaan atau ekonomi. Melalui pendidikan kewirausahaan, diharapkan 
masyarakat memiliki kemampuan untuk menyediakan lapangan kerja melalui identifikasi peluang dan penciptaan ide yang bermanfaat bagi pertumbuhan ekonomi negara sehingga berperan mengurangi pengangguran.

Tingkat pengangguran terbuka di kota Semarang dari Agustus 2011 sampai Agustus 2014 secara signifikan mengalami kenaikan (Anonim, Berita Resmi Statistik Propinsi Jawa Tengah, 2014). Berikut ini ditampilkan data mengenai tingkat pengangguran terbuka (TPT), yaitu banyaknya pengangguran terhadap 100 penduduk yang masuk kategori angkatan kerja di kota Semarang tahun 2011 sampai dengan tahun 2014.

Tabel 1

Data Jumlah Pengangguran Terbuka (TPT) di Kota Semarang Agustus 2011-2014

\begin{tabular}{|c|c|c|c|c|}
\hline Kota & $\mathbf{2 0 1 1}$ & $\mathbf{2 0 1 2}$ & $\mathbf{2 0 1 3}$ & $\mathbf{2 0 1 4}$ \\
\hline Kota Semarang & 6,92 & 5,82 & 6,02 & 7,76 \\
\hline
\end{tabular}

Sumber: BPS, 2014

Tabel 1 menunjukkan bahwa jumlah pengangguran terbuka di Semarang cenderung meningkat, bahkan per Agustus 2014 mencapai 7,76 persen. Sedangkan pada lingkup propinsi Jawa tengah, penyerapan tenaga kerja hingga Agustus 2014 masih didominasi oleh penduduk yang berpendidikan rendah yaitu SD ke bawah sebesar 8,98 juta orang (54,28 persen) dan Sekolah Menengah Pertama sebesar 3,12 juta orang $(18,84$ persen). Penduduk bekerja dengan pendidikan tinggi hanya sekitar 1,15 juta orang mencakup 0,32 juta orang $(1,97$ persen) berpendidikan diploma dan 0,83 juta orang $(5,00$ persen $)$ berpendidikan universitas.

Dengan tingginya tingkat pengangguran serta rendahnya lulusan universitas yang terserap ke lapangan kerja, maka menjadi tantangan bagi pihak perguruan tinggi sebagai lembaga penghasil lulusan untuk melakukan upaya dalam menumbuhkan intensi kewirausahaan, terutama merubah mindset mahasiswa yang selama ini hanya berminat menjadi pencari kerja.

Pendidikan kewirausahaan pada tingkat universitas/perguruan tinggi umumnya menjadi bagian dari mata kuliah Jurusan Manajemen (US News \& World Reports, 2009 dalam dalam Peltier dan Scovotti, 2010). Tetapi pengajar mata kuliah pemasaran semakin terlibat dalam memberikan pemahaman mengenai pendidikan kewirausahaan dan saat ini fokus supaya mahasiswa lebih berorientasi pada pemasaran kewirausahaan atau entrepreneurial marketing (Shaw, 2004).

Penelitian ini bertujuan untuk meneliti perspektif mahasiswa pada entrepreneurial mindset dan entrepreneurial marketing dengan menggunakan mahasiswa fakultas ekonomi Universitas Semarang yang mengambil konsen- trasi pemasaran sebagai subyek penelitian mengingat penelitian yang dilakukan oleh Peltier dan Scovotti (2010) dengan topik yang sama dilakukan pada mahasiswa di Amerika Serikat yang memiliki culture atau budaya yang berbeda dengan di Indonesia. Disamping itu, penelitian ini mencoba untuk melihat faktor-faktor penentu entrepreneurial mindset dan entrepreneurial marketing dengan menggunakan pendekatan gender.

\section{Perumusan Masalah}

Dari latar belakang yang telah dikemukakan, maka pertanyaan penelitian yang akan dikaji adalah:

1. Bagaimana persepsi mahasiswa Fakultas Ekonomi Jurusan Manajemen Universitas Semarang pada entrepreneurial mindset dan entrepreneurial marketing?

2. Apakah terdapat perbedaan entrepreneurial mindset dan dimensi entrepreneurial marketing pada mahasiswa pria dan wanita Fakultas Ekonomi Jurusan Manajemen Universitas Semarang?

\section{KAJIAN PUSTAKA}

\section{Kewirausahaan dan Wirausaha}

Banyak ahli yang mendefinisikan tentang kewirausahaan dan wirausaha. Hisrich dan Peters dalam Tunggal (2008) mendefinisikan kewirausahaan sebagai proses membuat sesuatu yang baru dengan mempertimbangkan resiko dan balas jasa. Menurut Zimmerer dalam Suryana (2006), kewirausahaan adalah suatu proses penerapan kreativitas dan keinovasian dalam memecahkan persoalan dan menemukan peluang untuk memperbaiki kehidupan, sedangkan Drucker dalam Suryana (2006) menyatakan bahwa kewirausahaan adalah kemampuan menciptakan sesuatu yang baru dan berbeda.

Scarborough dan Zimmerer dalam Tunggal (2008) mendefinisikan wirausaha sebagai orang yang melakukan reformasi atau merevolusi pola produksi dengan menggunakan penemuan atau teknologi yang belum dicoba untuk memproduksi komoditas baru atau memproduksi produk lama dengan cara baru. Sedangkan menurut Drucker dalam Tunggal (2008), wirausaha merupakan orang yang memindahkan sumber-sumber ekonomi yang produktivitasnya rendah menjadi sumber-sumber ekonomi berproduktivitas tinggi.

\section{Program Pendidikan Kewirausahaan}

Universitas merupakan tempat pelaksanaan pendidikan kewirausahaan dengan tujuan menyiapkan lulusan supaya dapat mandiri dan 
tidak berorientasi untuk menjadi pegawai. Program Pendidikan Kewirausahaan seharusnya menciptakan lingkungan yang berdampak pada pengalaman belajar mahasiswa dan membuat mahasiswa tertarik untuk menjadi wirausaha (Fuchs, Werner, \& Wallau, 2008; Souitaris, Verbinati, \& Al Laham, 2007). Menurut Teczke \& Gawlik (2004), tujuan utama universitas sebaiknya menekankan pada pengembangan kepribadian dan orientasi kewirausahaan.

Beberapa program pembekalan kewirausahaan yang dapat dilakukan oleh universitas diantaranya PKM (Program Kreativitas Mahasiswa), Program Kuliah Kewirausahaan atau Program Magang Kewirausahaan. Tetapi saat ini pengajar mata kuliah pemasaran semakin terlibat dalam memberikan pemahaman mengenai pendidikan kewirausahaan dan fokus supaya mahasiswa lebih berorientasi pada pemasaran kewirausahaan atau entrepreneurial marketing (Shaw, 2004).

\section{Entrepreneurial Mindset}

Dalam dunia pendidikan, program pendidikan kewirausahaan dikaitkan dengan usaha-usaha untuk meyaring kepribadian atau pola pikir (mindset) dari masing-masing individu (Raposo, do Paco, \& Ferreira, 2008). Kewirausahaan tidak hanya sekedar cara untuk memulai bisnis baru, tetapi juga menyiapkan siswa untuk memiliki karakteristik dan sifat-sifat yang terkait dengan orientasi kewirausahaan (Van, Louw, \& Venter, 2005).

Entrepreneurial mindset menjelaskan tentang keinovatifan dan semangat dalam mengejar peluang serta memfasilitasi tindakan untuk memanfaatkan peluang tersebut (Senges, 2007 dalam Scheepers, 2008). Pada tingkat individu, entrepreneurial mindset merupakan filosofi hidup, sedangkan pada tingkat organisasi, entrepreneurial mindset merupakan bagian dari budaya dan iklim perusahaan yang tidak dinyatakan secara jelas.

Salah satu indikator yang digunakan untuk mengukur entrepreneurial mindset adalah entrepreneurial self efficacy. Entrepreneurial self efficacy mengukur keyakinan seseorang pada kemampuannya untuk sukses menjadi wirausaha di masa yang akan datang (McGee, Peterson, Mueller, \& Sequeira, 2009)

\section{Entrepreneurial Marketing}

Morris, Schindehutte, \& La Forge (2002) memberikan definisi entrepreneurial marketing sebagai berikut "gagasan integratif untuk mengkonseptualisasikan pemasaran dalam era yang berubah, kompleks, kacau, kontradiktif dan kekurangan sumber daya, sehingga akan terlihat jelas pertumbuhan suatu perusahaan".
Entrepreneurial Marketing akan menyatukan aspek-aspek perkembangan pemikiran dan praktik pemasaran ke dalam area kewirausahaan sehingga menjadi suatu konsep yang menyeluruh.

Menurut Backbro \& Nystrom (2006), entrepreneurial marketing merupakan aspek tumpang tindih (overlapping) antara kewirausahaan dan pemasaran, yang ditunjukkan melalui perilaku setiap individu atau organisasi untuk membangun dan mempromosikan ide-ide pasar, serta mengembangkan ide-ide baru dalam rangka penciptaan nilai pelanggan. Sedangkan menurut Bjerke dan Hultman (2002) dalam Backbro dan Nystrom (2006) menyatakan bahwa entrepreneurial marketing adalah pemasaran untuk perusahaan kecil yang sedang tumbuh melalui kewirausahaan.

Entrepreneurial marketing merupakan konsep yang luas, tidak sekedar pemanfaatan strategi dan taktik pemasaran, bahkan merefleksikan sejauh mana perusahaan-perusahaan mengadopsi orientasi pemasaran ketika meluncurkan dan mengelola bisnis baru dan bisnis kecil, khususnya yang berkaitan dengan bagaimana perusahaan menciptakan dan mempertahankan proposisi nilai mereka (Kocak \& Abimbola, 2009).

Menurut Kraus, Harms, \& Fink (2010) definisi entrepreneurial marketing dapat dilihat dari dua perspektif, yaitu kualitatif dan kuantitatif. Definisi entrepreneurial marketing secara kualitatif menekankan pada aspek-aspek pemasaran untuk perusahaan kecil atau bisnis baru, sedangkan definisi entrepreneurial marketing secara kuantitatif menekankan pada aspek-aspek pemasaran dengan menggunakan jiwa/semangat kewirausahaan (entrepreneurial spirit). Walaupun demikian, kedua definisi tersebut saling melengkapi, pemasaran perusahaan kecil atau bisnis baru perlu dikelola oleh seorang entrepreneurial, yaitu orang yang punya jiwa proaktif, inovatif, risk-oriented, dan sebagainya.

\section{Gender sebagai Faktor yang Mempengaruhi Entrepreneurial Mindset dan Entrepreneurial Marketing}

Entrepreneurial mindset dan entrepreneurial marketing juga dipengaruhi oleh faktor-faktor demografi seperti gender atau jenis kelamin (Bosma, Acs, Coduras, \& Levie, 2008; Gupta, Turban, Wasti, \& Sikdar, 2009; Marlow, 2002). Teori feminisme sosialis yang dikembangkan oleh Kalleberg dan Leicht pada tahun 1991 menunjukkan bahwa karena adanya perbedaan dalam kehidupan bermasyarakat sejak muda, pria dan wanita berbeda secara inheren (Njeru, Bwisa, \& Kihoro, 2012). Namun demikian, hal ini bukan berarti bahwa wanita lebih inferior daripada pria. 
Pria dan wanita dapat menghasilkan hal yang berbeda dengan cara yang sama-sama efektif.

Penelitian mengenai kewirausahaan dengan menggunakan perspektif feminisme sosialis telah banyak dilakukan. Ada yang menyatakan bahwa terdapat perbedaan yang signifikan antara pria dan wanita terkait dengan kewirausahaan. Minniti, Arenius, \& Langowitz (2004) serta Reynolds, Bygrave, \& Autio (2004) membuktikan bahwa wanita cenderung kurang menyukai untuk membuka bisnis baru dibandingkan pria. Temuan yang berbeda disampaikan oleh Bosma, Acs, Coduras, \& Levie, (2008) bahwa wanita lebih suka menjadi wirausaha dibandingkan dengan pria. Sedangkan penelitian Njeru, Bwisa, \& Kihoro (2012) mengindikasikan bahwa gender merupakan faktor yang mempengaruhi secara signifikan hubungan antara entrepreneurial mindset dan kinerja bisnia.

Berdasarkan uraian tersebut, hipotesis yang diajukan dalam penelitian ini adalah sebagai berikut:

1. Entrepreneurial Mindset

$\mathrm{H}_{0}=$ Tidak terdapat perbedaan antara entrepreneurial mindset mahasiswa pria dan mahasiswa wanita

$\mathrm{H}_{\mathrm{a}}=$ Terdapat perbedaan antara entrepreneurial mindset mahasiswa pria dan mahasiswa wanita

2. Dimensi-dimensi Entrepreneurial Marketing $\mathrm{H}_{0}=$ Tidak terdapat perbedaan antara entrepreneurial marketing mahasiswa pria dan mahasiswa wanita

$\mathrm{H}_{\mathrm{a}}=$ Terdapat perbedaan antara entrepreneurial marketing mahasiswa pria dan mahasiswa wanita

\section{METODE PENELITIAN}

\section{Desain Penelitian}

Berdasarkan pada derajat kristalisasi pertanyaan penelitian, maka penelitian ini termasuk dalam formal study. Menurut Cooper dan Schindler (2008), formal study dimulai dengan suatu hipotesis atau pertanyaan penelitian yang kemudian melibatkan prosedur dan spesifikasi sumber data yang sesuai, yang bertujuan untuk menguji hipotesis atau jawaban atas pertanyaan penelitian yang diajukan. Metode pengumpulan data dalam penelitian ini merupakan communication study, yaitu peneliti mengajukan pertanyaan pada subyek penelitian dan mengumpulkan tanggapan mereka. Data dikumpulkan menggunakan kuesioner.

\section{Variabel Penelitian}

Variabel-variabel penelitian yang digunakan dalam penelitian ini adalah pola pikir kewirausahaan (entrepreneurial mindset), dan pemasaran kewirausahaan (entrepreneurial marketing).

\section{Definisi Operasional dan Pengukuran}

Entrepreneurial Mindset merupakan ciri-ciri utama yang menjadi tanda bahwa mahasiswa tertarik dengan kewirausahaan (entrepreneurial). Alat pengukuran yang digunakan untuk mengukur entrepreneurial mindset bersumber dari Peltier dan Scovotti (2010) dengan skala pengukuran dari $1=$ sangat tidak setuju sampai $5=$ sangat setuju. Indikatorindikator Entrepreneurial Mindset adalah sebagai berikut:

Tabel 2. Indikator Entrepreneurial Mindset

\begin{tabular}{|l|l|}
\hline Kode & \multicolumn{1}{|c|}{ Indikator } \\
\hline Ems1 & $\begin{array}{l}\text { Suatu hari nanti, saya tertarik untuk } \\
\text { memulai bisnis baru }\end{array}$ \\
\hline Ems2 & $\begin{array}{l}\text { Suatu hari nanti, saya tertarik } \\
\text { menjalankan bisnis kecil }\end{array}$ \\
\hline Ems3 & $\begin{array}{l}\text { Saya lebih memilih bekerja pada suatu } \\
\text { perusahaan dibandingkan menjadi } \\
\text { pemilik perusahaan }\end{array}$ \\
\hline Ems4 & $\begin{array}{l}\text { Dalam berbisnis, saya merupakan orang } \\
\text { yang berani mengambil resiko }\end{array}$ \\
\hline Ems5 & $\begin{array}{l}\text { Saya mempunyai keinginan yang kuat } \\
\text { untuk menjadi seorang pemimpin }\end{array}$ \\
\hline Ems6 & Saya memiliki kepribadian yang ramah \\
\hline Ems7 & $\begin{array}{l}\text { Saya memiliki ketrampilan komunikasi } \\
\text { yang baik }\end{array}$ \\
\hline Ems8 & $\begin{array}{l}\text { Saya memiliki ketrampilan organisasi } \\
\text { yang baik }\end{array}$ \\
\hline Ems9 & $\begin{array}{l}\text { Saya terlibat secara aktif dalam } \\
\text { organisasi kemahasiswaan }\end{array}$ \\
\hline Ems10 & $\begin{array}{l}\text { Saya ingin mendapatkan pengalaman } \\
\text { bisnis yang banyak }\end{array}$ \\
\hline Ems11 & $\begin{array}{l}\text { Saya memiliki minat yang kuat untuk } \\
\text { mengikuti magang }\end{array}$ \\
\hline Sumber: Pelier dan Scovotti 2010$)$
\end{tabular}

Sumber: Peltier dan Scovotti (2010)

Entrepreneurial Marketing adalah topik-topik kewirausahaan yang dianggap penting serta aktivitas belajar berdasarkan pengalaman yang bermanfaat untuk menjadi wirausaha atau menjalankan bisnis kecil. Entrepreneurial Marketing terdiri dari 5 dimensi meliputi strategi pemasaran untuk bisnis baru/kecil, peluncuran bisnis baru, teknologi komunikasi secara elektronik, membangun hubungan dan jaringan serta mengenal lebih mendalam mengenai entrepreneur.

Alat pengukuran yang digunakan untuk mengukur entrepreneurial marketing bersumber 
dari Peltier dan Scovotti (2010) dengan skala pengukuran dari 1 = sangat tidak penting sampai dengan $5=$ sangat penting. Indikator-indikator Entrepreneurial Marketing disajikan pada Tabel 3.

Tabel 3. Indikator Entrepreneurial Marketing

\begin{tabular}{|l|l|}
\hline \multicolumn{1}{|c|}{ Kode } & \multicolumn{1}{c|}{ Indikator } \\
\hline $\begin{array}{l}\text { Seberapa penting topik-topik kewirausahaan } \\
\text { berikut ini membantu anda menjadi wirausaha atau } \\
\text { menjalankan bisnis kecil: }\end{array}$ \\
\hline 1. Strategi pemasaran untuk bisnis baru/kecil \\
\hline SP1 & Pemasaran bisnis baru/kecil \\
\hline SP2 & Strategi periklanan bisnis baru/kecil \\
\hline SP3 & $\begin{array}{l}\text { Strategi personal selling (penjualan } \\
\text { personal) }\end{array}$ \\
\hline SP4 & $\begin{array}{l}\text { Strategi penetapan harga untuk bisnis } \\
\text { baru/kecil }\end{array}$ \\
\hline SP5 & $\begin{array}{l}\text { Pengembangan produk baru untuk bisnis } \\
\text { baru/kecil }\end{array}$ \\
\hline SP6 & Pengelolaan karyawan dan staf penjualan \\
\hline SP7 & Penentuan lokasi bisnis kecil/baru \\
\hline SP8 & Anggaran pemasaran bisnis kecil/baru \\
\hline 2. Peluncuran bisnis baru \\
\hline PB1 & Cara memulai bisnis baru \\
\hline PB2 & Cara menjalankan bisnis kecil dan baru \\
\hline PB3 & $\begin{array}{l}\text { Cara memperoleh pendanaan untuk } \\
\text { bisnis baru }\end{array}$ \\
\hline PB4 & Memahami semangat kewirausahaan \\
\hline 3. Teknologi komunikasi secara elektronik \\
\hline TK1 & $\begin{array}{l}\text { Strategi pembuatan web site untuk bisnis } \\
\text { kecil }\end{array}$ \\
\hline TK2 & Pemasaran dan teknologi \\
\hline TK3 & Komputer dan bisnis kecil \\
\hline TK4 & Strategi database pemasaran \\
\hline TK5 & Strategi email pemasaran \\
\hline 4. Membangun hubungan dan jaringan \\
\hline MHJ1 & $\begin{array}{l}\text { Memperbaiki ketrampilan membina } \\
\text { jaringan }\end{array}$ \\
\hline MHJ2 & Magang dengan pengusaha/wirausaha \\
\hline MHJ3 & Memperbaiki ketrampilan komunikasi \\
\hline entrepreneur \\
\hline MME1
\end{tabular}

Sumber: Peltier dan Scovotti (2010)

\section{Populasi dan Sampel}

Populasi adalah kumpulan orang, peristiwa atau dokumen mengenai informasi yang diharapkan dan dapat menjawab pertanyaan pengukuran (Cooper \& Schindler, 2008).. Dalam hal ini yang menjadi populasi penelitian adalah mahasiswa Universitas Semarang.
Sampel adalah sekelompok kejadian, partisipan, peristiwa atau dokumen yang merupakan bagian dari populasi target dan dipilih secara cermat untuk mewakili populasi (Cooper \& Schindler, 2008). Pengambilan sampel didasarkan pada metode penentuan sampel non probability dengan teknik purposive sampling. Adapun sampel dalam penelitian ini adalah mahasiswa Universitas Semarang Fakultas Ekonomi.

Jenis teknik purposive sampling yang digunakan adalah judgment sampling, dengan cara peneliti memilih anggota-anggota sampel untuk memenuhi kriteria tertentu (Cooper \& Schindler, 2008). Tidak semua mahasiswa Fakultas Ekonomi Universitas Semarang dijadikan sampel dalam penelitian ini, hanya mahasiswa Universitas Semarang yang memenuhi kriteria-kriteria yang ditentukan. Adapun kriteria yang digunakan adalah mahasiswa Fakultas Ekonomi Universitas Semarang jurusan S1 Manajemen dan mengambil mata kuliah seminar manajemen pemasaran.

\section{Metode Analisis Data}

Tahapan yang dilakukan dalam analisis data penelitian ini adalah sebagai berikut:

1. Menguji validitas dan reliabilitas indikatorindikator yang digunakan dalam pengukuran variabel.

Pengujian terhadap item-item kuesioner yang merupakan instrumen pengukuran dalam penelitian ini dilakukan dengan pengujian validitas dan reliabilitas. Validitas menunjukkan seberapa nyata suatu pengujian mengukur apa yang seharusnya diukur (Cooper \& Schindler, 2008). Sedangkan reliabilitas menunjukkan sebuah kondisi variabel yang konsisten dengan apa yang akan diukur (Hair, Black, Babin, Anderson, \& Tatham, 2006).

Pengujian validitas berupa pengujian secara kualitatif yang terdiri dari content validity dan face validity serta pengujian secara kuantitatif. Content validity menunjukkan peran dari butirbutir kuesioner telah mewakili konsep yang diukur dan face validity menunjukkan bahwa butir-butir kuesioner pengukur suatu konsep dari penampilan secara visual/ tampang telah mengukur konsep tersebut. Instrumen pengukuran diuji secara kualitatif untuk memenuhi content validity dan face validity dengan pertimbangan beberapa mahasiswa di Universitas Semarang. Sedangkan pengujian validitas secara kuantitatif dilihat dari membandingkan nilai Corrected Item - Total Correlation dibandingkan dengan nilai $\mathrm{r}$ tabel dengan tingkat $(\alpha) 0,05$. Kriteria keputusan, apabila nilai Corrected Item - Total Correlation lebih besar dari $\mathrm{r}$ tabel maka indikator layak (sahih) dan sebaliknya (Ghozali, 2005). 
Pengujian reliabilitas dilihat dari Cronbach's Alpha dengan bantuan software SPSS 16.0. Rule of thumb yang digunakan adalah nilai Cronbach's Alpha sebesar 0.7 atau lebih dari itu, tetapi nilai Cronbach's Alpha di atas 0.6 masih dapat diterima (Hair, Black, Babin, Anderson, \& Tatham, 2006). Semakin tinggi nilai Cronbach's Alpha berarti semakin reliabel alat ukur yang digunakan. Suatu kuesioner dikatakan reliabel atau handal jika jawaban seseorang terhadap pernyataan merupakan jawaban yang konsisten dari waktu ke waktu (Cooper \& Schindler, 2008).

2. Melakukan pengujian normalitas pada sampel yang digunakan.

Pengujian normalitas dilakukan dengan menggunakan Uji Kolmogorov Smirnov. Uji ini bertujuan untuk mengetahui apakah data berdistribusi normal atau tidak. Apabila data terdistribusi normal, maka digunakan statistik parametrik. Apabila data terdistribusi tidak normal, maka digunakan statistik non parametrik.

3. Melakukan analisis data deskriptif

Metode analisa data yang dilakukan dalam penelitian ini dengan menggunakan analisis data deskriptif. Analissi deskriptif yaitu analisis yang ditunjukkan pada perkembangan dan pertumbuhan dari suatu keadaan dan hanya memberikan gambaran tentang keadaan tertentu dengan cara menguraikan tentang sifat-sifat dari obyek penelitian tersebut (Umar, 2001).

4. Melakukan analisis angka indeks

Angka indeks pada dasarnya merupakan suatu angka yang dibuat sedemikian rupa sehingga dapat digunakan untuk melakukan perbandingan antara kegiatan yang sama pada waktu yang berbeda (Supranto, 1990).

5. Melakukan pengujian hipotesis komparatif

Penelitian ini menguji hipotesis komparatif dua sampel independen. Pengujian hipotesis komparatif dalam penelitian ini dilakukan dengan beberapa alternatif pengujian. Uji Mann Whitney menjadi alternatif ketika data tidak normal dalam uji independent sample t test, yaitu mengevaluasi apakah median pada dua kelompok berbeda. Apabila data terdistribusi normal, homogen dan tidak terdapat outlier, maka digunakan Independent $T$ Test. Apabila data terdistribusi tidak normal dan tidak homogen maka digunakan Kolmogorov-Smirnov Test.

\section{HASIL DAN PEMBAHASAN}

\section{Karakteristik Responden}

Penelitian ini mengambil objek pada mahasiswa Fakultas Ekonomi Universitas Semarang Jurusan Manajemen yang mengikuti mata kuliah Seminar Manajemen Pemasaran semester genap 2014/2015. Kuesioner penelitian didistribusikan secara langsung dengan tujuan untuk mendapatkan tingkat pengembalian yang tinggi. Kuesioner didistribusikan kepada 85 responden tetapi yang kembali dan digunakan untuk analisis 72 .

Tabel 4 menunjukkan bahwa lebih dari $50 \%$ responden berjenis kelamin perempuan. Berdasarkan minat menjadi wirausaha, dapat diketahui bahwa responden sebagian besar berminat menjadi wirausaha dalam waktu dekat yaitu sebesar $43,1 \%$, sedangkan $25 \%$ responden berminat menjadi wirausaha dalam waktu 2 tahun, dan $29,2 \%$ responden berminta menjadi wirausaha dalam jangka panjang. Sisanya yaitu 2,8\% responden tidak berminat menjadi wirausaha.

Tabel 4. Karakteristik Responden

\begin{tabular}{|c|c|c|}
\hline \multirow{2}{*}{ Karakteristik } & \multicolumn{2}{|c|}{ Jumlah Responden } \\
\hline & $\mathrm{N}$ & $\%$ \\
\hline Jenis Kelamin & & \\
\hline - Pria & 29 & $40,3 \%$ \\
\hline - Wanita & 43 & $59,7 \%$ \\
\hline $\begin{array}{l}\text { Minat Menjadi } \\
\text { Wirausaha }\end{array}$ & & \\
\hline - Dalam waktu dekat & 31 & $43,1 \%$ \\
\hline $\begin{array}{l}\text { - Dalam waktu } 2 \\
\text { tahun }\end{array}$ & 18 & $25 \%$ \\
\hline $\begin{array}{l}\text { - Dalam jangka } \\
\text { panjang }\end{array}$ & 21 & $29,2 \%$ \\
\hline $\begin{array}{l}\text { - Tidak berminat } \\
\text { menjadi wirausaha }\end{array}$ & 2 & $2,8 \%$ \\
\hline
\end{tabular}

Sumber: Data primer diolah, 2015

Tabel 4 menunjukkan bahwa lebih dari $50 \%$ responden berjenis kelamin perempuan. Berdasarkan minat menjadi wirausaha, dapat diketahui bahwa responden sebagian besar berminat menjadi wirausaha dalam waktu dekat yaitu sebesar $43,1 \%$, sedangkan $25 \%$ responden berminat menjadi wirausaha dalam waktu 2 tahun, dan $29,2 \%$ responden berminta menjadi wirausaha dalam jangka panjang. Sisanya yaitu $2,8 \%$ responden tidak berminat menjadi wirausaha.

\section{Uji Validitas dan Reliabilitas}

Uji validitas dan reliabilitas digunakan untuk mengukur kesahihan dan kevalidan suatu item pertanyaan. Kriteria keputusannya adalah dengan membandingkan nilai Corrected Item Total Correlation dibandingkan dengan nilai $\mathrm{r}$ tabel (72) dengan tingkat $(\alpha)$ 0,05 yaitu sebesar 0,2319 . Kriteria keputusan, apabila nilai Corrected Item - Total Correlation lebih besar dari $\mathrm{r}$ tabel maka indikator layak (sahih) dan sebaliknya (Ghozali, 2005).

Uji instrumen yang lain adalah uji reliabilitas yaitu berhubungan dengan masalah 
ketepatan dari suatu data. Pengujian reliabilitas melalui nilai koefisien alpha dengan dibandingkan nilai 0,60. Konstruk atau variabel dikatakan reliabel apabila mempunyai nilai alpha diatas 0,60 dan sebaliknya (Ghozali, 2005).

Berdasarkan hasil perhitungan dengan program SPSS, diperoleh nilai korelasi indikator Ems2 dan indikator Ems3 kurang dari 0,2319. Karena koefisien korelasi pada dua indikator tersebut nilainya kurang dari 0,2319 maka dapat disimpulkan bahwa kedua indikator tersebut tidak berkorelasi signifikan dengan skor total (dinyatakan tidak valid) sehingga harus dikeluarkan. Sedangkan sebagian besar indikator (selain indikator Ems2 dan indikator Ems3) adalah valid, hal ini ditandai dengan nilai Corrected Item - Total Correlation $>\mathrm{r}$ tabel $(0,2319)$. Pembuktian ini menunjukkan bahwa semua indikator tersebut layak digunakan sebagai indikator dari konstruk (laten variabel). Koefisien alpha (cronbach alpha) memiliki nilai di atas 0,60 sehingga dapat dijelaskan bahwa variabel - variabel penelitian (konstruk) yang berupa variabel entrepreneurial mindset, strategi pemasaran untuk bisnis baru/ kecil, peluncuran bisnis baru, teknologi komunikasi secara elektronik, membangun hubungan dan jaringan serta mengenal lebih mendalam mengenai entrepreneur adalah reliabel atau memiliki reliabilitas yang tinggi, sehingga mempunyai ketepatan untuk dijadikan variabel (konstruk) pada suatu penelitian.

\section{Angka Indeks \\ Angka indeks digunakan untuk mendapatkan gambaran mengenai derajad persepsi responden atas variabel yang diteliti (Ferdinand, 2011). Dalam penelitian ini, peneliti menghitung nilai indeks indikator-indikator entrepreneurial mindset, strategi pemasaran untuk bisnis baru/ kecil, peluncuran bisnis baru, teknologi komuni- kasi secara elektronik, membangun hubungan dan jaringan serta mengenal lebih mendalam mengenai entrepreneur.}

\section{Angka Indeks untuk Indikator-indikator Entrepreneurial Mindset}

Dari tabel perhitungan angka indeks dapat dilihat bahwa hampir semua indikator entrepreneurial mindset pada mahasiswa pria dan wanita mempunyai angka indeks yang masuk dalam kategori yang sama yaitu tinggi kecuali indikator ketrampilan organisasi yang baik. Hal ini menunjukkan bahwa secara umum mahasiswa pria dan wanita fakultas Ekonomi USM yang mengambil konsentrasi pemasaran memiliki ketertarikan yang tinggi untuk membuka usaha sendiri atau menjadi wirausaha.
Disisi yang lain, hanya satu indikator yang memiliki nilai indeks dengan kategori sedang yaitu indikator ketrampilan organisasi yang baik. Hal ini memberikan satu indikasi bahwa walaupun mahasiswa tertarik untuk membuka usaha sendiri, mereka cenderung kurang percaya diri dengan kemampuan organisasinya.

Perbedaan kategori nilai indeks berada pada indikator keberanian mengambil resiko dan keinginan untuk magang. Mahasiswa pria ternyata memiliki keberanian mengambil resiko lebih tinggi dibandingkan mahasiswa wanita. Sedangkan dalam hal keinginan untuk magang, mahasiswa wanita memiliki keinginan magang lebih tinggi dibandingkan mahasiswa pria.

\section{Angka Indeks untuk Indikator-indikator Entrepreneurial Marketing \\ Pada variabel entrepreneurial} marketing, nilai indeks semua indikator yang merupakan dimensi strategi pemasaran untuk bisnis baru/kecil, dimensi peluncuran bisnis baru, dimensi membangun hubungan dan jaringan serta dimensi mengenal lebih mendalam mengenai entrepreneur, baik untuk mahasiswa pria maupun wanita menunjukkan kategori tinggi. Hal ini menunjukkan bahwa topik-topik tersebut dianggap merupakan materi yang penting bagi mahasiswa pria maupun wanita sebagai bekal untuk menjadi wirausaha yang sukses.

Berbeda dengan empat dimensi variabel entrepreneurial marketing yang lain, indikator dimensi teknologi komunikasi secara elektronik tidak semuanya memberikan hasil yang sama pada mahasiswa pria dan wanita, yaitu termasuk dalam kategori tinggi. Hanya ada dua indikator yang termasuk dalam kategori tinggi. Kedua indikator tersebut adalah pemasaran dan teknologi serta komputer dan bisnis kecil. Sedangkan indikator yang memberikan hasil kategori yang berbeda adalah strategi pembuatan website untuk bisnis kecil, strategi database pemasaran dan strategi email pemasaran.

Bagi mahasiswa pria, indikator strategi pembuatan website untuk bisnis kecil, indikator strategi database pemasaran dan indikator strategi email pemasaran masuk dalam kategori sedang, sedangkan bagi mahasiswa wanita, ketiga indikator tersebut termasuk kategori tinggi. Hal ini menunjukkan bahwa mahasiswa wanita masih memerlukan topik-topik mengenai strategi pembuatan website untuk bisnis kecil, database pemasaran dan strategi email pemasaran sehingga menganggap topik-topik tersebut sangat penting untuk menunjang pengetahuan mereka tentang entrepreneurship. Sedangkan mahasiswa pria menganggap bahwa ketiga topik tersebut tingkat kepentingannya berada pada tingkat sedang. 
Sebuah penelitian mengenai pengaruh perbedaan gender pada penggunaan teknologi informasi model TAUT menunjukkan bahwa niat menggunakan sistem informasi lebih tinggi pengaruhnya pada wanita dan lebih tinggi pengaruhnya pada pengguna yang lebih berpengalaman (Bendi \& Aliyanto, 2014). Berdasarkan penelitian tersebut, penjelasan yang paling memungkinkan adalah bahwa mahasiswa wanita lebih mempunyai pengalaman di dalam menggunakan teknologi informasi seperti pemanfaatan website maupun email sehingga tingkat kepentingan mahasiswa wanita mengenai topok-topik yang berkaitan dengan teknologi komunikasi secara elektronik termasuk dalam kategori tinggi. Tabel 5 merangkum hasil perhitungan angka indeks masing-masing indikator.

Tabel 5. Hasil Perhitungan Angka Indeks

\begin{tabular}{|c|c|c|c|c|c|c|c|c|c|c|c|c|c|c|c|}
\hline \multirow[t]{2}{*}{ Indikator } & \multicolumn{5}{|c|}{$\begin{array}{l}\text { Frek. Jawaban } \\
\text { Responden Pria }\end{array}$} & \multirow[t]{2}{*}{ Indeks } & \multirow[t]{2}{*}{ Kategori } & \multirow[t]{2}{*}{ Indikator } & \multicolumn{5}{|c|}{$\begin{array}{c}\text { Frek. Jawaban } \\
\text { Responden Wanita }\end{array}$} & \multirow[t]{2}{*}{ Indeks } & \multirow[t]{2}{*}{ Kategori } \\
\hline & 1 & 2 & 3 & 4 & 5 & & & & 1 & 2 & 3 & 4 & 5 & & \\
\hline \multicolumn{16}{|c|}{ Entrepreneurial Mindset } \\
\hline Ems1 & 0 & 0 & 2 & 17 & 10 & 24,8 & Tinggi & $\mathrm{X} 1 \_1$ & 0 & 0 & 4 & 16 & 23 & 38,2 & Tinggi \\
\hline Ems4 & 0 & 0 & 7 & 18 & 4 & 22,6 & Tinggi & $\mathrm{X} 1 \_4$ & 1 & 3 & 18 & 14 & 7 & 30,4 & Sedang \\
\hline Ems5 & 0 & 0 & 4 & 12 & 13 & 25,0 & Tinggi & $\mathrm{X} 1 \_5$ & 0 & 1 & 10 & 18 & 14 & 34,8 & Tinggi \\
\hline Ems6 & 0 & 0 & 4 & 14 & 11 & 24,6 & Tinggi & X1_6 & 0 & 0 & 7 & 22 & 14 & 35,8 & Tinggi \\
\hline Ems7 & 0 & 0 & 9 & 13 & 7 & 22,8 & Tinggi & X1_7 & 0 & 1 & 12 & 21 & 9 & 33,4 & Tinggi \\
\hline Ems8 & 0 & 0 & 13 & 11 & 5 & 21,6 & Sedang & $\mathrm{X} 1 \_8$ & 0 & 1 & 19 & 20 & 3 & 30,8 & Sedang \\
\hline Ems9 & 0 & 2 & 16 & 5 & 6 & 20,4 & Sedang & X1_9 & 1 & 7 & 20 & 9 & 6 & 28,2 & Sedang \\
\hline Ems10 & 0 & 0 & 3 & 9 & 17 & 26,0 & Tinggi & X1_10 & 0 & 0 & 7 & 21 & 15 & 36,0 & Tinggi \\
\hline Ems11 & 1 & 1 & 9 & 14 & 4 & 21,2 & Sedang & X1_11 & 0 & 0 & 19 & 16 & 8 & 32,2 & Tinggi \\
\hline \multicolumn{16}{|c|}{ Strategi Pemasaran untuk Bisnis Baru/Kecil } \\
\hline SP1 & 0 & 0 & 7 & 19 & 3 & 22,4 & Tinggi & $\mathrm{X} 2 \_1$ & 0 & 0 & 14 & 16 & 13 & 34,2 & Tinggi \\
\hline SP2 & 0 & 2 & 9 & 12 & 6 & 21,8 & Tinggi & $\mathrm{X} 2 \_2$ & 0 & 0 & 13 & 21 & 9 & 33,6 & Tinggi \\
\hline SP3 & 0 & 0 & 14 & 10 & 5 & 21,4 & Tinggi & $\mathrm{X} 2 \_3$ & 0 & 0 & 18 & 14 & 11 & 33,0 & Tinggi \\
\hline SP4 & 0 & 0 & 2 & 17 & 10 & 24,8 & Tinggi & X2_4 & 0 & 0 & 6 & 22 & 15 & 36,2 & Tinggi \\
\hline SP5 & 1 & 0 & 1 & 19 & 8 & 24,0 & Tinggi & X2_5 & 0 & 0 & 3 & 24 & 16 & 37,0 & Tinggi \\
\hline SP6 & 0 & 0 & 8 & 14 & 7 & 23,0 & Tinggi & X2_6 & 0 & 0 & 5 & 27 & 11 & 35,6 & Tinggi \\
\hline SP7 & 0 & 0 & 6 & 13 & 10 & 24,0 & Tinggi & X2_7 & 0 & 0 & 4 & 19 & 20 & 37,6 & Tinggi \\
\hline SP8 & 0 & 0 & 5 & 14 & 10 & 24,2 & Tinggi & X2_8 & 0 & 0 & 8 & 19 & 16 & 36,0 & Tinggi \\
\hline \multicolumn{16}{|c|}{ Peluncuran Bisnis Baru } \\
\hline PB1 & 0 & 0 & 2 & 21 & 6 & 24,0 & Tinggi & X3_1 & 0 & 0 & 4 & 23 & 16 & 36,8 & Tinggi \\
\hline PB2 & 0 & 0 & 5 & 18 & 6 & 23,4 & Tinggi & $\mathrm{X} 3 \_2$ & 0 & 0 & 6 & 21 & 16 & 36,4 & Tinggi \\
\hline PB3 & 0 & 0 & 5 & 12 & 12 & 24,6 & Tinggi & X3_3 & 0 & 0 & 9 & 18 & 17 & 36,8 & Tinggi \\
\hline PB4 & 1 & 1 & 3 & 12 & 12 & 24,0 & Tinggi & X3_4 & 0 & 0 & 6 & 19 & 18 & 36,8 & Tinggi \\
\hline \multicolumn{16}{|c|}{ Teknologi Komunikasi secara Elektronik } \\
\hline TK1 & 0 & 0 & 12 & 15 & 2 & 21,2 & Sedang & X4_1 & 0 & 2 & 9 & 18 & 14 & 34,6 & Tinggi \\
\hline TK2 & 0 & 1 & 4 & 14 & 10 & 24,0 & Tinggi & $\mathrm{X} 4 \_2$ & 0 & 1 & 6 & 19 & 17 & 36,2 & Tinggi \\
\hline TK3 & 0 & 0 & 8 & 19 & 2 & 22,0 & Tinggi & $\mathrm{X} 4 \_3$ & 0 & 0 & 12 & 19 & 12 & 34,4 & Tinggi \\
\hline TK4 & 0 & 0 & 12 & 16 & 1 & 21,0 & Sedang & $\mathrm{X} 4 \_4$ & 0 & 0 & 14 & 18 & 11 & 33,8 & Tinggi \\
\hline TK5 & 0 & 0 & 21 & 8 & 0 & 19,0 & Sedang & X4_5 & 0 & 0 & 16 & 19 & 8 & 32,8 & Tinggi \\
\hline \multicolumn{16}{|c|}{ Membangun Hubungan dan Jaringan } \\
\hline MHJ1 & 0 & 0 & 8 & 16 & 5 & 22,6 & Tinggi & X5_1 & 0 & 0 & 11 & 20 & 12 & 34,6 & Tinggi \\
\hline MHJ2 & 0 & 0 & 8 & 14 & 7 & 23,0 & Tinggi & X5_2 & 0 & 0 & 11 & 16 & 16 & 35,4 & Tinggi \\
\hline MHJ3 & 0 & 0 & 1 & 14 & 14 & 25,8 & Tinggi & X5_3 & 0 & 0 & 5 & 16 & 22 & 37,8 & Tinggi \\
\hline
\end{tabular}




\begin{tabular}{|c|c|c|c|c|c|c|c|c|c|c|c|c|c|c|c|}
\hline \multicolumn{16}{|c|}{ Mengenal lebih Mendalam mengenai Entrepreneur } \\
\hline MME1 & 0 & 0 & 3 & 17 & 9 & 24,4 & Tinggi & X6_1 & 0 & 0 & 2 & 26 & 15 & 37,0 & Tinggi \\
\hline MME2 & 0 & 0 & 4 & 17 & 8 & 24,0 & Tinggi & X6_2 & 0 & 0 & 2 & 22 & 19 & 37,8 & Tinggi \\
\hline terendah & 29 & 0 & 0 & 0 & 0 & 5,8 & & terendah & 43 & 0 & 0 & 0 & 0 & 8,6 & \\
\hline tertinggi & 0 & 0 & 0 & 0 & 29 & 29,0 & & tertinggi & 0 & 0 & 0 & 0 & 43 & 43,0 & \\
\hline \multicolumn{8}{|c|}{ Rentang $=29,0-5,8=23,2$} & \multicolumn{8}{|c|}{ Rentang $=43,0-8,6=34,4$} \\
\hline \multicolumn{8}{|c|}{ Kategori dengan three box method: $23,2 / 3=7,7$} & \multicolumn{8}{|c|}{ Kategori dengan three box method: $34,4 / 3=11,5$} \\
\hline \multicolumn{8}{|c|}{ Dasar interpretasi nilai indeks $=$} & \multicolumn{8}{|c|}{ Dasar interpretasi nilai indeks $=$} \\
\hline $5,8-13,5$ & $=$ & \multicolumn{6}{|c|}{ Rend } & $8,6-20,1$ & \multicolumn{7}{|c|}{$=$ Renc } \\
\hline $13,6-21,2$ & $=$ & \multicolumn{6}{|c|}{ Sedang } & $20,2-31,7$ & $=$ & \multicolumn{6}{|c|}{ Sedang } \\
\hline $21,3-29$ & $=$ & \multicolumn{6}{|c|}{ Tinggi } & $31,8-43$ & $=$ & \multicolumn{6}{|c|}{ Tingoi } \\
\hline
\end{tabular}

Sumber: Data Primer yang Diolah, 2015

Tabel 6. Hasil Uji Normalitas dan Uji Homogenitas

\begin{tabular}{|l|l|l|l|l|}
\hline No & \multicolumn{1}{|c|}{ Dimensi } & \multicolumn{1}{|c|}{$\begin{array}{c}\text { Hasil Uji } \\
\text { Normalitas }\end{array}$} & $\begin{array}{c}\text { Hasil Uji } \\
\text { Homogenitas }\end{array}$ & $\begin{array}{c}\text { Uji Beda yang } \\
\text { Digunakan }\end{array}$ \\
\hline 1. & Entrepreneurial Mindset & Normal & Homogen & Uji Independent T-Test \\
\hline 2. & Entrepreneurial Marketing & Normal & Homogen & Uji Independent T-Test \\
\hline
\end{tabular}

Sumber: Data primer diolah, 2015

\section{Uji Normalitas, Homogenitas dan Outliers}

Normalitas merupakan syarat keharusan pada análisis parametrik. Jika asumsi ini dilanggar, maka uji statistik menjadi tidak valid atau bias terutama untuk sampel kecil. Uji normalitas dalam penelitian ini menggunakan metode $\mathrm{Uji}$ Kolmogorov-Smirnov dan Uji Shapiro-Wilk. Jika signifikansi dibawah 0,05 berarti data yang akan diuji mempunyai perbedaan yang signifikan dengan data normal baku, berarti data tersebut tidak normal, sedangkan jika signifikansi diatas 0,05 maka data terdistribusi normal.

Uji homogenitas digunakan untuk mengetahui apakah beberapa varian populasi adalah sama atau homogen. Asumsi yang mendasari dalam análisis varian adalah bahwa varian dari populasi adalah sama. Uji homogenitas dalam penelitian ini menggunakan metode Levene's Test. Sebagai kriteria pengujian, jika nilai signifikansi lebih dari 0,05 maka dapat dikatakan bahwa varian dari dua atau lebih kelompok data adalah sama.

Outliers adalah data yang menyimpang terlalu jauh dari data yang lainnya dalam suatu rangkaian data. Adanya data outliers ini akan membuat analisis terhadap serangkaian data menjadi bias, atau tidak mencerminkan fenomena yang sebenarnya. Istilah outliers juga sering dikaitkan dengan nilai esktrem, baik ekstrem besar maupun ekstrem kecil. Deteksi outlier bisa dinilai dengan box-plot. Jika data simetris (berasal dari distribusi normal), garis median akan berada di tengah box dan whisker bagian atas dan bawah akan memiliki panjang yang sama serta tidak terdapat nilai outlier ataupun nilai ekstrim. Dalam penelitian ini, jika ada data yang terindikasi outlier, data-data ini tetap dipertahankan karena merupakan elemen dari populasi yang ada, sehingga patut untuk dipertahankan untuk alasan generabilitas. Jika outliers ini dibuang, peneliti akan mendapatkan hasil analisis multivariat yang lebih baik tetapi tidak pada aspek generabilitas ((Hair, Black, Babin, Anderson, \& Tatham, 2006). Hasil uji normalitas dan homogenitas pada tiaptiap dimensi dirangkum pada Tabel 6 berikut ini:

\section{Pengujian Hipotesis}

Pengujian hipotesis dalam penelitian ini dilakukan dengan uji Independent T-Test terhadap variabel entrepreneurial mindset dan entrepreneurial marketing pada dua kelompok mahasiswa dengan kode 1 untuk mahasiswa pria dan kode 2 untuk mahasiswa wanita. Tabel 7 merangkum hasil pengujian hipotesis yang dilakukan. Uraian tiap hipotesis dan pembahasan akan dijelaskan lebih lanjut.

Tabel 7. Hasil Uji Independent T Test

\begin{tabular}{|l|c|}
\hline \multicolumn{1}{|c|}{ Variabel } & Sig. (2-tailed) \\
\hline Entrepreneurial Mindset & 0,245 \\
\hline Entrepreneurial Marketing & 0,124 \\
\hline
\end{tabular}




\section{Uji Hipotesis 1}

Hipotesis 1 dalam penelitian ini adalah sebagai berikut:

$\mathrm{H}_{0}$ : Tidak terdapat perbedaan antara entrepreneurial mindset mahasiswa pria dan mahasiswa wanita

$\mathrm{H}_{\mathrm{a}}$ : Terdapat perbedaan antara entrepreneurial mindset mahasiswa pria dan mahasiswa wanita

Berdasarkan data dari hasil pengolahan data diketahui bahwa nilai t hitung sebesar 0,245. Nilai $\mathrm{t}$ hitung ini lebih besar daripada 0,05. Sehingga dapat disimpulkan bahwa $\mathrm{H}_{0}$ dapat diterima.

\section{Uji Hipotesis 2}

Hipotesis 2 dalam penelitian ini adalah sebagai berikut:

$\mathrm{H}_{0}$ : Tidak terdapat perbedaan antara entrepreneurial marketing mahasiswa pria dan mahasiswa wanita

$\mathrm{H}_{\mathrm{a}}$ : Terdapat perbedaan antara entrepreneurial marketing mahasiswa pria dan mahasiswa wanita

Berdasarkan data dari hasil pengolahan data diketahui bahwa nilai t hitung sebesar 0,124. Nilai $\mathrm{t}$ hitung ini lebih besar daripada 0,05 . Sehingga dapat disimpulkan bahwa $\mathrm{H}_{0}$ dapat diterima.

\section{Pembahasan}

Hasil penelitian ini secara umum menunjukkan bahwa tidak ada perbedaan entrepreneurial mindset dan entrepremeurial marketing antara mahasiswa pria dan mahasiswa wanita. Hasil ini berbeda dengan dengan penelitian-penelitian yang lain. Misalnya penelitian Minniti, Arenius, \& Langowitz (2004) serta penelitian dan Reynolds, Bygrave, \& Autio (2004) membuktikan bahwa wanita cenderung kurang menyukai untuk membuka bisnis baru dibandingkan pria. Sedangkan penelitian Njeru, Bwisa, \& Kihoro (2012) mengindikasikan bahwa gender merupakan faktor yang mempengaruhi secara signifikan hubungan antara entrepreneurial mindset dan kinerja bisnis.

Namun demikian, penelitian ini sejalan dengan penelitian (Indarti \& Rostiani, 2008) yang menemukan bahwa gender tidak mempengaruhi intensi berwirausaha pada mahasiswa dan tidak terbukti bahwa mahasiswa pria memiliki intensi berwirausaha yang lebih tinggi dibandingkan mahasiswa wanita. Penelitian Chairy (2011) juga menunjukkan bahwa tidak ada perbedaan intensi berwirausaha antara mahasiswa pria dan wanita. Penelitian Indarti dan Rostiani (2004) serta penelitian Chairy (2011) mengambil sampel mahasiwa, sama dengan penelitian ini. Dengan demikian dapat disimpulkan bahwa akses pendidikan yang sama antara mahasiswa pria dan wanita membuat tidak ada perbedaan antara entrepreneurial mindset mahasiswa pria dan wanita.

Peltier \& Scavoti (2010) menyatakan ada empat komponen yang digunakan dalam pendidikan wirausaha yaitu knowledge base (pengetahuan dasar), skill sets (sejumlah ketrampilan), fasilitas, serta ikatan komunitas. Dalam kaitannya dengan empat komponen tersebut, Universitas Semarang menyediakan platform komponen Entrepreneurial Education Program, pusat inovasi atau sejenisnya, mencakup pengetahuan dasar dari berbagai jenis bisnis, beragam keahlian, fasilitas di mana pendidikan berlangsung dan keterkaitan dengan masyarakat melalui alumni, dunia usaha dan industri serta organisasi lain dan/atau lembaga pemerintah. Disamping itu Universitas Semarang tidak membedakan perlakuan antara mahasiswa pria dan mahasiswa wanita dalam penerimaan program pendidikan kewirausahaan serta program-program kewirausahaan lainnya (PKM, PMW, Organisasi Mahasiswa Wirausaha (SPC)) dan kegiatan sejenisnya. Dengan demikian membawa dampak pada tidak adanya perbedaan dalam penilaian kepentingan dimensi entrepreneurial marketing.

\section{SIMPULAN}

\section{Simpulan}

Penelitian ini menghasilkan kesimpulan atas hipotesis yang diajukan, sebagaimana diuraikan berikut ini

1. Tidak terdapat perbedaan antara entrepreneurial mindset mahasiswa pria dan mahasiswa wanita.

2. Tidak terdapat perbedaan antara entrepreneurial marketing mahasiswa pria dan mahasiswa wanita.

\section{Saran} ini adalah :

Saran yang dapat diberikan dari penelitian

1. Penelitian ini hanya dilakukan pada mahasiswa di Universitas Semarang saja. Untuk generalisasi penelitian, perlu dilakukan studi yang melibatkan mahasiswa dengan jumlah yang lebih besar dan melibatkan mahasiswa dari beberapa universitas di Semarang. Disamping itu perlu diteliti lebih lanjut apakah perbedaan sistem pengajaran dan lingkungan di perguruan tinggi, misalnya antara perguruan tingggi negeri dan swasta 
dapat menghasilkan entrepreneurial mindset yang berbeda pula.

2. Akan lebih baik lagi kalau terdapat variasi lokasi penelitian yang lebih beragam, misalnya berbeda kota. Mahasiswa yang tinggal di Semarang mungkin memiliki mindset yang berbeda dengan mahasiswa yang berada di kota besar lain seperti Bandung, Yogyakarta, Surabaya dan lain-lain.

3. Penelitian ini hanya menggunakan gender sebagai indikator yang digunakan untuk membedakan entrepreneurial mindset dan entrepreneurial marketing. Perlu digunakan indikator-indikator lain, seperti misalnya kategori pekerjaan orang tua (entrepreneur dan non-entrepreneur), etnis, atau usia. Dengan demikian perbedaan jenis indikator dapat dieksplorasi lebih lanjut kemungkinannya sebagai faktor pembentuk entrepreneurial mindset dan entrepreneurial marketing mahasiswa.

\section{DAFTAR PUSTAKA}

Anonim. (2014, November 5). Berita Resmi Statistik Proponsi Jawa Tengah. VIII(70/11/33). Semarang, Jawa Tengah, Indonesia: Badan Pusat Statistik Propinsi Jawa Tengah.

Backbro, J., \& Nystrom, H. (2006). Entrepreneurial Marketing: Innovative Value Creation . Master's Thesis, Jonkoping University, Jonkoping International Business School.

Bendi, R. J., \& Aliyanto, A. (2014). Pengaruh Perbedaan Gender pada Model UTAUT. Seminar Nasional Teknologi Informasi dan Komunikasi Terapan 2014, (pp. 228234). Semarang.

Bosma, N., Acs, Z. J., Coduras, A., \& Levie, J. (2008). Retrieved June 16, 2015, from www.gemconsortium.org.

Budiati, Y., Yani, T. E., \& Universari, N. (2012, Juni). Minat Mahasiswa menjadi Wirausaha: Studi pada Mahasiswa Fakultas Ekonomi Universitas Semarang. Jurnal Dinamika Sosial Budaya, 14(1), 89-101.

Bumpus, M. A., \& Burton, G. (2008). Chapter in the Life of an Entrepreneur: a Case Study. Journal of Education for Business, 83(5), 302-308.

Chairy. (2011). Pengaruh Karakteristik Entrepreneurial, Jenis Etnis, Jenis Kelamin dan Profesi Orang Tua terhadap intensi Berwirausaha Mahasiswa. Jurnal Manajemen \& Bisnis, 1(2), 245-259.
Cooper, D. R., \& Schindler, P. S. (2008). Business Research Methods. New York, NY: McGraw-Hill/Irwin.

Dickson, P. H., Solomon, G. T., \& Weaver, K. M. (2008). Entrepreneurial Selection and Success: Does Education Matter? Journal of Small Business and Enterprise Development, 15(2), 239-258.

Ferdinand, A. (2011). Metode Penelitian Manajemen. Semarang: Badan Penerbit Universitas Diponegoro.

Frank, H., Lueger, M., \& Korunka, C. (2007). The Significance of Personality in Business Start-Up Intentions, Star-Up Realization and Business Success. Entrepreneurship and Regional Development, 19(3), 227.

Fuchs, K., Werner, A., \& Wallau, F. (2008). Entrepreneurship Education in Germany and Sweden: What Role Do Different School Systems Play? Journal of Small Business and Enterprise Development, 15(2), 365-381.

Ghozali, I. (2005). Aplikasi Analisis Multivariate dengan Program SPSS. Semarang: Badan Penerbit Universitas Diponegoro.

Gupta, V. K., Turban, D. B., Wasti, S. A., \& Sikdar, A. (2009). The role of Gender Stereotypes in Perceptions of Entrepreneus and Intentions to Become an Entrepreneur. Entrepreneurship Theory and Practice, 34(3), 397-417.

Hair, J. F., Black, W. C., Babin, B. J., Anderson, R. E., \& Tatham, R. L. (2006). Multivariate Data Analysis. Upper Sadle River: NJ: Pearson Educational, Inc.

Halbesleben, J. R. (2004). Balance is The Key: A Conversation with J. Clifford Hudson. Journal of Applied Management and Entrepreneurship, 9(3), 114-119.

Indarti, N., \& Rostiani, R. (2008). Intensi Kewirausahaan Mahasiswa: Studi Perbandingan antara Indonesia, Jepang dan Norwegia. Jurnal Ekonomika dan Bisnis Indonesia, 23(4), 1-27.

Indriantoro, N., \& Supomo, B. (2001). Metodologi Penelitian Bisnis. Yogyakarta: BPFE.

Kirby, D. A. (2004). Entrepreneurship Education: Can Business Schools Meet The Challenge? Education+Training, 46(8/9), 510-519.

Kocak, A., \& Abimbola, T. (2009). The Effects of Entrepreneurial Marketing on Born Global Performance. International Marketing Review, 26(4/5), 439-452.

Kraus, S., Harms, R., \& Fink, M. (2010). Entrepreneurial Marketing: Moving Beyond Marketing in New Ventures. International Journal Entrepreneurship 
and Innovation Management, 11(1), 1934.

Kuratko, D. F. (2004). Entrepreneurship Education in the 21st Century: from Legitimization to Leadership. A Coleman Foundation White Paper USASBE National Conference.

Marlow, S. (2002). Women and Self-Employment A PArt of or Apart from Theoretical Construct? International Journal of Entrepreneurship and Innovation, 3(2), 83-91.

McGee, J. E., Peterson, M., Mueller, S. L., \& Sequeira, J. M. (2009). Entrepreneurial Self-Efficacy: Refining the Measure. Entrepreneurship Theory and Practice, 33(4), 965-988.

Millman, C., \& Matlay, H. (2008). Entrepreneurship Education in China: a Case Study Approach. Journal of Small Business and Enterprise Development, 15(5), 802-815.

Minniti, M., Arenius, P., \& Langowitz, N. (2004). Global Entrepreneurship Monitor: 2004 Report on Women and Entrepreneurship. Babson College. Boston MA.

Morris, M., Schindehutte, M., \& La Forge, R. W. (2002). Entrepreneurial Marketing: A Construct for Integrating Emerging Entrepreneurship and Marketing Perspectives. Journal of Marketing Theory and Practice, 10(4), 1-18.

Njeru, P. W., Bwisa, H. M., \& Kihoro, J. M. (2012). Gender Based Entrepreneurial Mindset and Their Influence on Performance of Small and Medium Manufacturing Firms. International Journal of Business and Commerce, 1(9), 182-198.

Peltier, J. W., \& Scovotti, C. (2010). Enhancing Entrepreneurial Marketing Education: the Student Perspective. Journal of Small Business and Enterprise Development, 17(4), 514-536.

Raposo, M., do Paco, A., \& Ferreira, J. (2008). Entrepreneur's Profile: A Taxonomy of Attributes and Motivations of University Students. Journal of Small Business and Enterprise Development, 15(2), 404-418.

Reynolds, P. D., Bygrave, W. D., \& Autio, E. (2004). Global Entrepreneurship monitor 2003 Executive Report. Babson College, London Business School and Kauffman Foundation.

Sari, M. (2014, Maret). Entrepreneurterhadap Kinerja UKM di Kota Medan. Jurnal Riset Akuntansi dan Bisnis, 14(1), 52-65.
Scheepers, M. J. (2008). Entrepreneurial Mindset of Information and Communication Technology Firms. Journal of Information Management, 10(4).

Shane, S., \& Venkataraman, S. (2000). The Promise of Entrepreneurship as a Field of Research. Academy of Management Review, 25(1), 217-226.

Shaw, E. (2004). Entrepreneurial Marketing: The Growth of Small Firms in The New Economic Era. International Small Business Journal, 22(1), 110-112.

Shinnar, R., Pruett, M., \& Toney, B. (2009). Entrepreneurship Education: Attitudes Across Campus. Journal of Education for Business, 84(3), 151-159.

Souitaris, V., Verbinati, S., \& Al Laham, A. (2007). Do Entrepreneurship Programmes Raise Entrepreneurial Intentions of Science and Engineering Students? The Effect of Learning Inspiration and Resources. Journal of Business Venturing, 22(4), 566-591.

Stokes, D. (2000). Putting Entrepreneurship into Marketing. Journal of Research in Marketing \& Entrepreneurship, 2(1), 116.

Supranto, J. (1990). Statistik Teori dan Aplikasi. Jakarta: Penerbit Erlangga.

Suryana. (2006). Kewirausahaan: Pedoman Praktis. Jakarta: Penerbit Salemba.

Teczke, J., \& Gawlik, R. (2004). The Implications of Academic Entrepreneurship for University Administration. Higher Education in Europe, 29(2), 201-204.

Tunggal, A. W. (2008). Pengantar Kewirausahaan. Jakarta: Penerbit Harvarindo.

Umar, H. (2001). Metode Penelitian untuk Skripsi dan Tesis Bisnis. Jakarta: Raja Grafindo Persada.

Van, E. S., Louw, L., \& Venter, D. (2005). Entrepreneurial Traits of Undergraduate Commerce Students: A Three-Country Comparison. Management Dynamic, 14(3), 26-43

Wiratno, S. (2012). Pelaksanaan Pendidikan Kewirausahaan di Pendidikan Tinggi. Jurnal Pendidikan dan Kebudayaan, 18(4), 453-466 